\title{
The Development of E-Book Learning Media Based PBL
}

\author{
Charles Fransiscus Ambarita \\ Economic Education Study \\ Program \\ State University of Medan \\ Medan, Indonesia
}

\author{
Dita Eka Pertiwi Sirait \\ Business Education Study \\ Program \\ State University of Medan \\ Medan, Indonesia
}

\author{
Dody Feliks Pandimun \\ Ambarita \\ Primary School Teacher \\ Education Study Program \\ State University of Medan \\ Medan, Indonesia
}
Harvei Desmon Hutahaean
Informatics and Computer
Engineering Education Study
Program
State University of Medan
Medan, Indonesia

\author{
Rotua Sahat Pardamean \\ Simanullang \\ Office Administration \\ Education Study Program \\ State University of Medan \\ Medan, Indonesia
}

\begin{abstract}
Revolution 4.0 requires college students to be able to have skills in solving problems. The rapid development of technology and the outbreak of the COVID-19 pandemic require the learning process is done online. This is certainly very different from the faceto-face learning process before the pandemic era. The object of this research is Learning Planning e-book based PBL. E-book developed using the Kvisoft Flipbook Maker application. Students' perceptions of the developed e-book learning media with Kvisoft Flipbook Maker application based PBL on Learning Planning course is included in the very good category with an average score of 4.34. While, regarding the effectiveness of the e-book learning media developed with the PBL-based Kvisoft Flipbook Maker application in the Lesson Planning course, there is an increase after using the e-book learning media compared with before using the e-book. After using the e-book learning media obtained a total of 2690 with an average 84.06 on the very good criteria but before using the e-book obtained a total of 1850 with an average of 57.81 being in the deficient criteria.
\end{abstract}

Keywords: Development, Learning Planning E-book Based PBL, Students' Perceptions, Effectiveness

\section{INTRODUCTION}

Education is a crucial part of the civilization of a nation. A nation that has competitiveness is the result of a planned education in the long term. The development of technology in the era of the industrial revolution 4.0, which is commonly called the very fast information era are excellent tools to achieve high civilization and support in the world of education. Along with that, this development has been hampered because the world is currently being hit by a corona virus outbreak, including in Indonesia. Since February 2020, the corona virus pandemic has hit Indonesia.

The government responded to the high spread of the corona virus by releasing circular about online learning and working from home in order to prevent the spread of Covid-19 [1]. One of the things contained in this circular is to replace faceto-face learning with network- based learning (online) through e-learning used by various educational institutions. Medan State University as part of educational institutions in Indonesia, also applies the same thing, namely implementing online learning starting in March 2020.

Lecturers as the spearhead of learning in the classroom are required to be able to develop online learning media. Learning tool such as Semester Learning Plan (RPS) are designed according to the online learning that will be implemented. Online learning media is a tool for lecturers to deliver learning materials that can stimulate the minds and wills of students in the learning process. Learning media requires students to take an active role in learning and use media as learning device and by changing student behavior in the teaching and learning process [2]. One of the online learning media that can be developed by lecturers is e-book learning media.

Digital book or also called e-book, is a publication that consists of text, images, sounds and published in digital form that can be read on computer or other electronic devices such as android, or tablet [3]. This can be interpreted that e-book or digital book is a copy of the concept of teaching materials that are poured by lecturers digitally in the form of text, images, sounds and others that are packaged interactively to increase the enthusiasm of learning from students. Using this e-book, students are expected to be more active in learning and create new variation of learning where so far, the conventional way of learning is through printed books or dictation. The e-book in this study uses the Kvisoft Flipbook Maker application. Kvisoft Flipbook Maker is a suitable software when used as a learning media because in this application it is possible to add various features such as motion animation, video, images, and audio that can be interactive learning media so that it can attract students' interest and make teaching and learning activities not monotonous [4]. The selection of Kvisoft Flipbook Maker is the right choice and in accordance with the characteristics of Learning Planning course, where Learning 
Planning course is dominated by theoretical concepts. In this Kvisoft Flipbook Maker software there are several features to add hyperlink, images, videos, and audios. So that with this feature it is able to make it easier for students when they will understand material related to technology videos in the world of offices in the current digital era [4].

One way to improve student learning outcomes is to train how to solve problems in course studies. Problem Based Learning (PBL) is a learning approach that starts with posing a problem and continues by solving the problem [5]. With problem solving skills, students, both in groups and individually, will be able to think critically and creatively so that mastery of lecture material can be achieved as a whole and comprehensively. The concept of the PBL method begins with identifying problems in learning and then making observations either in the classroom or out the classroom to be able to solve problems scientifically.

Based on the background of the problems described above, the problem that becomes the study material in this research is how is students' perceptions and effectiveness of the developed e-book learning media with Kvisoft Flipbook Maker application based PBL on Learning Planning course? The purpose of this study was to determine students' perceptions and effectiveness of the developed e-book learning media with Kvisoft Flipbook Maker application based PBL on Learning Planning course.

\section{METHOD}

The type of research used is research and development. Borg dan Gall defined that educational research and development $(\mathrm{R} \& \mathrm{D})$ is a process used to develop and validate educational products. The steps of this process are usually referred to as the R\& D cycle, which consists of studying research findings pertinent to the product to be developed, developing the product based on the finding, field testing it in the setting where it will be used eventually, and revising it to correct the deficiencies found in the field-testing stage [6]. This research will produce an e-book based PBL in Learning Planning course.

The model used in this study is $4 \mathrm{D}$ (four-D models). On the other hand, Sugiyono stated that four-D model consists of 4 main stages, namely: 1) define, 2) design, 3) develop, and 4) disseminate [7]. In this paper, only the disseminate stage is explained because the define, design and develop stages have been published in the previous article.

The instruments used in this study were questionnaire and test. Questionnaire is used to obtain data about students' perceptions of the developed product and test is used to obtain data about the effectiveness of the developed product. The research data were analyzed to determine students' perceptions and effectiveness of the developed product. The students' perceptions of the developed product can be seen from individual trial response result and small group trial response result. The effectiveness of the developed product can be seen from the pretest and posttest answered by the college students in the limited field group trial response result.

\section{RESULTS AND DISCUSSIONS}

\subsection{Results}

Individual trial was carried out on 3 students in the third semester of the Economic Education study program for the 2021/2022 academic year, Faculty of Economics, State University of Medan. While, the small group trial was carried out on 9 students in the third semester of the Economic Education study program for the 2021/2022 academic year, Faculty of Economics, State University of Medan. The results of the individual trial response, small group trial response and limited field group trial response can be seen in the following table.

Table 1. The Individual and Small Group Trial Response Results

\begin{tabular}{|c|c|c|c|c|}
\hline \multirow[t]{2}{*}{ No. } & \multirow[t]{2}{*}{ Indicators } & \multicolumn{2}{|c|}{ Score of Trial Results } & \multirow{2}{*}{$\begin{array}{c}\text { Average } \\
\text { Score of } \\
\text { Trial } \\
\text { Results }\end{array}$} \\
\hline & & Individual & $\begin{array}{l}\text { Small } \\
\text { Group }\end{array}$ & \\
\hline 1. & $\begin{array}{l}\text { Selection of font } \\
\text { type and size }\end{array}$ & 4.33 & 4.4 & 4.37 \\
\hline 2. & $\begin{array}{l}\text { Color selection } \\
\text { accuracy }\end{array}$ & 4 & 4.33 & 4.17 \\
\hline 3. & $\begin{array}{c}\text { Color combination } \\
\text { accuracy }\end{array}$ & 4.33 & 4.27 & 4.3 \\
\hline 4. & Material display & 4 & 4.47 & 4.24 \\
\hline 5. & Text legibility & 4.67 & 4.33 & 4.5 \\
\hline 6. & Material clarity & 4.67 & 4.47 & 4.57 \\
\hline 7. & Ease of use & 4 & 4.4 & 4.2 \\
\hline 8. & $\begin{array}{l}\text { Clear instructions } \\
\text { for use }\end{array}$ & 4.33 & 4.27 & 4.3 \\
\hline 9. & Media attraction & 4.33 & 4.53 & 4.43 \\
\hline 10. & $\begin{array}{c}\text { Ease of } \\
\text { understanding }\end{array}$ & 4.33 & 4.33 & 4.33 \\
\hline \multicolumn{4}{|c|}{ Total Average Trial Score } & 4.34 \\
\hline \multicolumn{4}{|c|}{ Category } & Very Good \\
\hline
\end{tabular}

The table shows that the indicator related to the selection of font type and size get an average value of 4.37, color selection accuracy of 4.17 , color combination accuracy of 4.3 , material display of 4.24 , text legibility of 4.5 , material clarity of 4.57 , ease of use of 4.2 , clear instructions for use is 4.3 , media attraction is 4.43 , and ease of understanding is 4.33 . Based on the table, it can be concluded that the students' perceptions of the developed e-book learning media is included in the very good category with an average score of 4.34 . 
Limited field group trial was carried out on class $C$ students in the third semester of the Economic Education study program for the 2021/2022 academic year, Faculty of Economics, State University of Medan as many as 32 people. In this trial, students were given a pre-test and a post-test. This is done to determine the effectiveness of e-book learning media. The test results can be seen in the following table.

Table 2. Pre-test dan Post-test Results

\begin{tabular}{|c|c|c|}
\hline No & Pre-test & Post-test \\
\hline 1 & 60 & 85 \\
\hline 2 & 60 & 80 \\
\hline 3 & 45 & 85 \\
\hline 4 & 60 & 90 \\
\hline 5 & 55 & 95 \\
\hline 6 & 60 & 90 \\
\hline 7 & 55 & 85 \\
\hline 8 & 50 & 80 \\
\hline 9 & 65 & 85 \\
\hline 10 & 50 & 75 \\
\hline 11 & 65 & 90 \\
\hline 12 & 55 & 85 \\
\hline 13 & 55 & 80 \\
\hline 14 & 50 & 75 \\
\hline 15 & 60 & 80 \\
\hline 16 & 65 & 80 \\
\hline 17 & 60 & 85 \\
\hline 18 & 55 & 75 \\
\hline 19 & 70 & 95 \\
\hline 20 & 55 & 85 \\
\hline 21 & 60 & 95 \\
\hline 22 & 50 & 80 \\
\hline 23 & 55 & 75 \\
\hline 24 & 55 & 95 \\
\hline
\end{tabular}

\begin{tabular}{|c|c|c|}
\hline 25 & 65 & 80 \\
\hline 26 & 60 & 80 \\
\hline 27 & 65 & 95 \\
\hline 28 & 55 & 90 \\
\hline 29 & 65 & 90 \\
\hline 30 & 60 & 75 \\
\hline 31 & 50 & 80 \\
\hline 32 & 60 & 75 \\
\hline Total & 1850 & 2690 \\
\hline Average & 57.81 & 84.06 \\
\hline
\end{tabular}

The table shows that the pretest of college students obtained a total of 1850 with an average of 57.81 being in the deficient criteria, while the posttest or in other words the test carried out after the application of e-book learning media obtained a total of 2690 with an average 84.06 on the very good criteria. Based on the table, it can be concluded that the average score obtained by college students has increased where after using the e-book learning media, it was 84.06 compared to 57.81 before using the e-book.

\subsection{Discussions}

In trial to students or users, the average result of the perceptions on the individual trial response and small group trial response is 4.34 , meaning that the e-book learning media is already in the very good category. While in the limited field group trial response, it is known that the average score obtained by college students has increased where after using the e-book learning media, it was 84.06 compared to 57.81 before using the e-book. This is in line with research conducted by Roesnita Ismail and Zainab AN in a journal entitled The Pattern of E-Book Use Amongst Undergraduates in Malaysia: A Case of To Know Is to Use, where it is stated that the positive rate for e-book services is around $70 \%$. Those who use e-books find e-books easy to use and their use is especially needed for writing assignments or project work. This is indirectly able to increase the effectiveness of learning

\section{CONCLUSIONS}

Students' perceptions of the developed e-book learning media with Kvisoft Flipbook Maker application based PBL on Learning Planning course is included in the very good category with an average score of 4.34. Regarding the developed e-book learning media with Kvisoft Flipbook Maker application based PBL on Learning Planning course, there is an increase after using the e-book learning media compared with before using the e-book. After using the ebook learning media obtained a total of 2690 with an average 84.06 on the very good criteria but before using the e-book obtained a total of 1850 with an average of 57.81 being in the deficient criteria. 


\section{ACKNOWLEDGMENT}

Special thanks to Prof. Dr. Baharuddin, M.Pd. for the funds that have been given through the Community Service Institute of State University of Medan, may you always be blessed by God Almighty in your work, health, long life and all elements of life.

\section{REFERENCES}

[1] Makarim NA. Surat Edaran Menteri Pendidikan Dan Kebudayaan Nomor 4 Tahun 2020. Indonesia: Menteri Pendidikan dan Kebudayaan Indonesia; 2020.

[2] Peprizal SN. Pengembangan Media Pembelajaran Berbasis Web Pada Mata Kuliah Fisika Modern. J Ilmu Pendidik dan Pembelajaran. 2020; 4(3):455-467.

[3] Mentari D, Sumpono S, Ruyani A. Pengembangan media pembelajaran e-book berdasarkan hasil riset elektroforesis 2-d untuk mengukur kemampuan berpikir kreatif mahasiswa. PENDIPA J. Sci. Educ. 2018; 2(2):131-134.

[4] Fitri ER, Pahlewi T. Pengembangan LKPD Berbantuan Kvisoft Flipbook Maker pada Mata Pelajaran Teknologi Perkantoran di SMKN 2 Nganjuk. J Pendidik Adm Perkantoran. 2020; 9(2):281-291.

[5] Siswono TYE. Upaya Meningkatkan Kemampuan Berpikir Kreatif Siswa Melalui Pengajuan Masalah. J Pendidik Mat dan Sains. 2005; 10(1):1-9.

[6] Borg, W.R. \& Gall, M.D. Gall. (1983). Educational Research: An Introduction, Fifth Edition. New York: Longman.

[7] Sugiyono. Metode Penelitian Kuantitatif, Kualitatif, dan R\&D. Bandung: Alfabeta; 2013. 